\title{
Educational evaluation of renewable energy projects based on RETScreen software
}

\section{Evaluación educativa de proyectos de energías renovables basados en el software RETScreen}

MENDOZA-GONZÁLEZ, Felipe †*, HERNANDEZ-ESCOBEDO, Quetzalcoatl, VARGAS, Alejandro and CÓRDOVA-ESCOBEDO, Jesús Fausto

Universidad Veracruzana, Faculty of Engineering Coatzacoalcos region - Minatitlán, Mexico.

ID $1^{\text {st }}$ Author: Felipe, Mendoza-González / ORC ID: 0000-0003-1172-6782, Researcher ID: S-6747-2018, CVU CONACYT ID: 947336

ID $1^{\text {st }}$ Co-author: Quetzalcoatl, Hernández-Escobedo / ORC ID: 0000-0002-2981-7036, Researcher ID: M-2414-2014, CVU CONACYT ID: 220140

ID $2^{\text {nd }}$ Co-author: Alejandro, Vargas / ORC ID: 0000-0002-6889-2610, Scopus Author ID: 13607626400, Researcher ID: C-1997-2012

ID $3^{\text {rd }}$ Co-author: Jesús Fausto, Córdova-Escobedo / ORC ID: 0000-0002-7456-6897, Researcher ID: S-6737-2018, CVU CONACYT ID: 511561

DOI: $10.35429 / J I T C .2020 .12 .4 .17 .22$

Received July 10, 2020; Accepted December 30, 2020

\begin{abstract}
In the design of renewable energy projects, a present problem is the techno-economic evaluation of them, regularly different methods and models are used to do it, in this work it is proposed to innovate in the degree of Engineering in Renewable Energies (LIER) of the UNAM in the National School of Superior Studies Juriquilla campus the way to evaluate projects using the software RETScreen. This paper presents a methodology to evaluate a wind energy project in the state of Queretaro Mexico. The project contemplates a wind turbine brand VESTAS V44 - 40m of $600 \mathrm{~kW}$ capacity of $40 \mathrm{~m}$ height in the state of Querétaro in the center of the country of Mexico. The initial costs of this wind turbine are 1,283 $\$ / \mathrm{kW}$ or $770,000 \mathrm{USD}$, with a rate of $80 \$ / \mathrm{kW}$. The electricity exported to the grid is $1,703 \mathrm{MWh}$ and the income from electricity exports is $136,235.52$ USD. With this wind turbine you can save $1,318.2 \mathrm{tCO}_{2}$ per year or 566,414 liters of unused gasoline.
\end{abstract}

Projects, Renewable energies, Education

\begin{abstract}
Resumen
En el diseño de proyectos de energías renovables un problema presente es la evaluación tecno-económica de ellos, regularmente se utilizan diferentes métodos y modelos para hacerlo, en este trabajo se propone innovar en la licenciatura de Ingeniería en Energías Renovables (LIER) de la UNAM en la Escuela Nacional de Estudios Superiores campus Juriquilla la forma de evaluar proyectos utilizando el software RETScreen. En este trabajo se presenta una metodología para evaluar un proyecto de energía eólica en el estado de Querétaro México. El proyecto contempla un aerogenerador marca VESTAS V44 - 40m de $600 \mathrm{~kW}$ de capacidad de $40 \mathrm{~m}$ de altura en el estado de Querétaro en el centro del país de México. Los costos iniciales de este aerogenerador son de $1,283 \$ / \mathrm{kW}$ o 770,000 USD, con una tarifa de $80 \$ / \mathrm{kW}$. La electricidad exportada a la red eléctrica es de 1,703 MWh y los ingresos por exportación de electricidad es de 136,235.52 USD. Con este aerogenerador se pueden ahorrar 1,318.2 $\mathrm{tCO}_{2}$ al año o 566,414 litros de gasolina no utilizados.
\end{abstract}

Proyectos, Energías renovables, Educación

Citation: MENDOZA-GONZÁLEZ, Felipe, HERNANDEZ-ESCOBEDO, Quetzalcoatl, VARGAS, Alejandro and CÓRDOVA-ESCOBEDO, Jesús Fausto. Educational evaluation of renewable energy projects based on RETScreen software. Journal of Information Technologies and Communications. 2020. 4-13:17-22.

\footnotetext{
* Correspondence to Author (E-mail: femendoza@uv.mx)

$\dagger$ Researcher contributing as first author.
} 


\section{Introduction}

Renewable energy is the current trend of obtaining energy. Numerous scientists, inventors, and engineers are working to harness renewable energy. The application of renewable energy is very broad; It can be as small as the illumination of an LED bulb or as large as the electricity generation of a city or even a country. Wind energy plays an important role in the context of electricity generation, it depends both on the speed of the wind at a site and on the atmospheric conditions, its orography and roughness. It can only be considered as a wind resource until these variables have been considered. Its evaluation is necessary for the design and evaluation of wind sites that every professional in this area should consider. Renewable energy is the current trend of obtaining energy. Numerous scientists, inventors, and engineers are working to harness renewable energy. The trend of the application of renewable energy is due to the saturation of carbon dioxide in the atmosphere as described (Li et al., 2020). Although carbon dioxide could be absorbed by plants during the day through photosynthesis, excessive carbon dioxide emission and illegal deforestation contributed to global warming (Sikarwar et al., 2020). The effects of global warming have recently been seen and found by humanity. Rising sea water could sink some islands and countries in the coming decades.

The application of renewable energy is very broad; It can be as small as the illumination of an LED bulb or as large as the electricity generation of a city or even a country. Wind energy plays an important role in the context of electricity generation (Wang et al., 2020). Wind power is highly dependent on the speed of the wind at a wind site. Wind prediction is necessary for an assessment of the wind energy of a potential wind farm (Adetokun et al., 2020). The exploitation of wind energy for power generation is taking an important role in the consumption of electricity worldwide. Proper use of the wind resource could maximize its capacity factor and minimize electricity costs (Alkhalidi et al., 2020). The global wind power production capacity has doubled about three times, from $147 \mathrm{GW}$ at the end of 2008 to 435 GW at the end of 2015 .
It has been deployed by many countries such as the United States, Germany, Spain, China, India, the United Kingdom and Egypt. China is considered to be the dominant country in this field where its installed capacity is 145 $\mathrm{GW}$, followed by the United States with $73 \mathrm{GW}$, Germany $45 \mathrm{GW}$, India $25 \mathrm{GW}$, Spain $23 \mathrm{GW}$ and the United Kingdom 14 GW (Enevoldsen \& Sovacool, 2016).

This document is based on a novel approach to clean energy production. Specifically, the role of Earth observation (EO) satellites in maximizing renewable energy production is considered to show the enormous potential for exploitation of sustainable power generation plants when the Earth is mapped by satellites to provide some peculiar parameters (eg solar irradiation, wind speed, rainfall, weather conditions, geothermal data). Within this framework, RETScreen (Canada, 2010) clean energy management software can be used for numerical analysis, such as energy generation and efficiency, pricing, emission reduction, financial feasibility, and risk of various types of renewable energy and energy efficiency technologies, based on an extensive database of satellite parameters. This simplifies initial assessments and provides streamlined processes that allow funders, architects, designers, regulators, etc., to make decisions about future clean energy initiatives. In this paper, the use of RETScreen software is proposed to evaluate a wind energy project in the state of Querétaro. The software divides the evaluation procedure into stages, starts with the type of project, site selection, analysis of meteorological variables, selection of technology, costs and financial benefits, risk analysis and finally determines the economic viability.

\section{Methodology}

In this project RETScreen software is used for project evaluation, this software is a clean energy management system for the feasibility analysis of energy efficiency, renewable energy and cogeneration projects, as well as for the continuous analysis of energy performance, The methodology used will serve for the training of future Renewable Energy Engineers of the National School of Higher Studies in the Juriquilla unit (ENES-J) of the National Autonomous University of Mexico (UNAM). Figure 1 shows the RETScreen work process. 


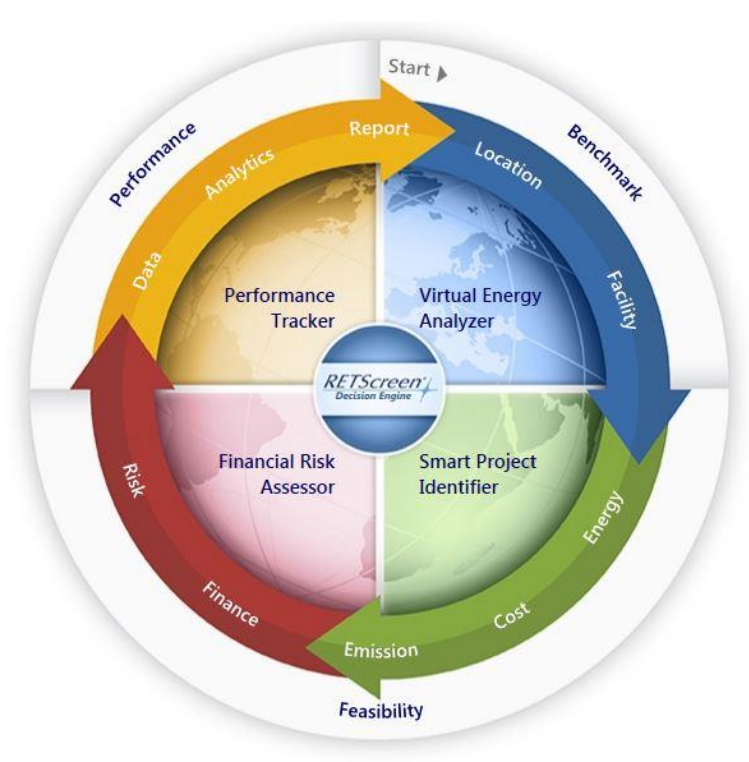

Figure 1 Flowchart

Source: RETScreen, 2020

According to Figure 1, the site data begins, that is, meteorological data and the project to be carried out are requested; The second step is to choose the energy model. In this step, variables such as systems interconnected to the electrical network or isolated are considered; The third stage is the evaluation of the costs in the project, here the initial investment, the debt, the costs for operation and maintenance will be entered and the software will return the financial viability, that is, the payback period, the net present value and the internal rate of return; the fourth stage is related to the amount of greenhouse gas emissions that can be saved with the project; finally the fifth stage is a sensitivity analysis and risk analysis

\section{Project description}

A VESTAS V44 - 40m $600 \mathrm{~kW}$ capacity $40 \mathrm{~m}$ high wind turbine or wind turbine generation plant is considered in the state of Querétaro in the center of the country of Mexico. The initial costs of this wind turbine are $\$ 1,283 / \mathrm{kW}$ or 770,000 USD, with a tariff of $\$ 80 / \mathrm{kW}$. The electricity exported to the power grid is 1,703 $\mathrm{MWh}$ and the electricity export revenue is 136,235.52 USD.

The location of the state of Querétaro is presented in Figure 2.

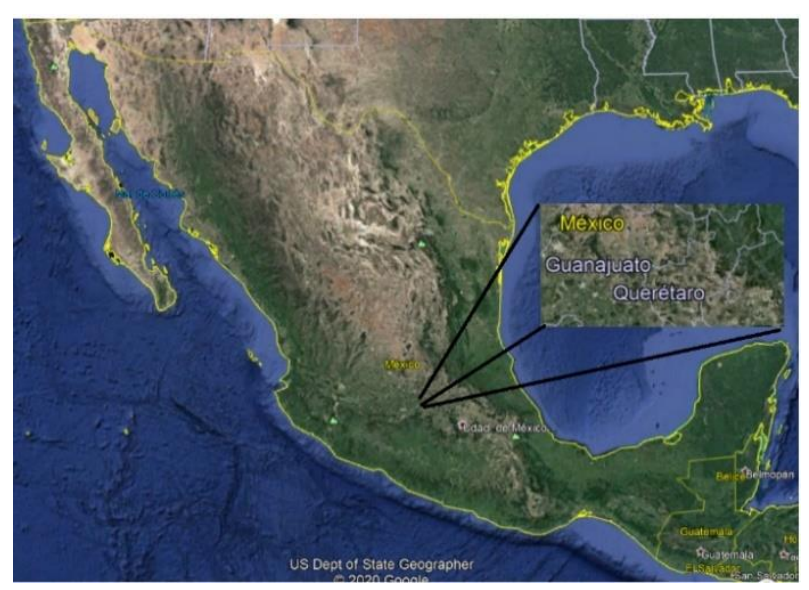

Figure 2 Geographical position of the state of Querétaro, Mexico

Source: Google earth, 2020

RETScreen works with data provided by the National Aeronautics and Space Administration of the United States of North America (NASA for its acronym in English), these data include meteorological variables such as wind speed and global solar radiation, in Figure 3 they are shown these two variables related to each other.

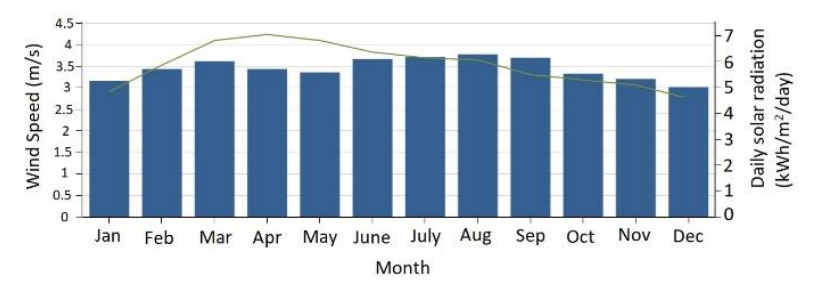

Figure 3 Wind speed and global solar radiation in Querétaro Mexico

Source: RETScreen, 2020

Among the calculations carried out by the software is the determination of the Internal Rate of Return or IRR, this is finding the discount rate that makes the net present value of the patrimony equal to zero. Therefore, it is not necessary to set an organization's discount rate to use this indicator. An organization interested in a project can compare the internal rate of return with its required rate of return (often the cost of capital). The IRR is calculated on a nominal basis (that is, including inflation).

If the internal rate of return is equal to or greater than the organization's required rate of return, then the project is likely to be considered financially acceptable (assuming the same risk). If it is lower than the required rate of return, the project is usually rejected. 
An organization may have multiple required rates of return that will vary based on the perceived risk of the projects. The most obvious advantage of using the rate of return indicator to evaluate a project is that the result does not depend on a specific discount rate of a given organization. Instead, the IRR obtained is project specific and applies to all investors in the project.

Another variable to determine is the project's net present value (NPV), which is the value of all future cash flows, discounted at the discount rate, in today's currency. The NPV is related to the internal rate of return (IRR). Thus, the NPV is calculated at time 0 which corresponds to the union of the end of year 0 and the beginning of year 1 . According to the NPV method, the present value of all cash inflows is compared with the present value of all cash outflows associated with an investment project. The difference between the present value of these cash flows, called NPV, determines whether the project is generally a financially acceptable investment. Positive NPV values are an indicator of a potentially viable project. When using the net present value method, you need to choose a rate to discount cash flows to present value. As a practical matter, organizations spend a lot of time and study choosing a discount rate. The model calculates the NPV using cumulative after-tax cash flows.

The model also calculates the net benefit / cost ratio (B-C), which is the ratio of net benefits to project costs. Net benefits represent the present value of annual income and savings minus annual costs, while cost is defined as the equity of the project.

Ratios greater than 1 are indicative of profitable projects. The net benefit / cost ratio, similar to the profitability ratio, leads to the same conclusion as the net present value indicator.

The software calculates return on capital, which represents the time it takes for a proposed facility to recover its own initial cost, based on the income or savings it generates. The basic premise of the simple payback method is that the faster the cost of an investment can be recovered, the more desirable the investment, i.e., in the case of a power project execution, a negative payback period would be a indication that the annual costs incurred are higher than the annual savings generated.
The simple payback method is not a measure of the profitability of one project compared to another. Rather, it is a measure of time in the sense that it indicates how many years it takes to recoup the investment of one project compared to another. The simple repayment method should not be used as a primary indicator to evaluate a project. However, it is useful as a secondary indicator to indicate the level of risk of an investment.

Moreover, the payback period is usually of great importance to individuals or small businesses that may be cash poor. When a company is cash-poor, a project with a short payback period, but a low rate of return, may be preferred to a project with a high rate of return, but a long payback period. The reason is that the organization may simply need a faster payback on its cash investment. The model uses total startup costs, total annual costs (excluding debt payments), and total annual savings and income to calculate simple repayment. The calculation is based on pre-tax amounts and includes any initial cost incentives and grants.

The model calculates the accumulated reduction of greenhouse gases (GHG) during the duration of the project, in equivalent tons of $\mathrm{CO} 2$ ( $\mathrm{tCO} 2)$, resulting from the application of the proposed case system (evaluation of the wind turbine).

\section{Results}

Table 1 shows the financial results, it is important to mention that the currency used is the US dollar (USD).

\begin{tabular}{|l|l|r|}
\hline \multicolumn{3}{|c|}{ Financial analysis } \\
\hline Rate of inflation & $\%$ & 4.5 \\
\hline Project life time & year & 25 \\
\hline Debt ratio & $\%$ & 60 \\
\hline Interest rate & $\%$ & 8.5 \\
\hline Duration of debt & year & 10 \\
\hline Startup costs & $\$$ & $1,223,437$ \\
\hline Total annual costs & $\$$ & 159,539 \\
\hline Electricity export earnings & $\$$ & 136,236 \\
\hline Financial Viability & & 10.5 \\
\hline Internal rate of return & $\%$ & 13.8 \\
\hline Return of Capital & year & 61,928 \\
\hline Net present value & $\$$ & 1.1 \\
\hline Benefit / cost ratio & $\%$ & \\
\hline
\end{tabular}

Table 2 
As can be seen in table 1 , the internal rate of return (IRR) is $10.5 \%$, which is interpreted as that the investment is attractive if we compare the IRR with a bank investment rate; The return on capital shows that the project investment will be recovered in 13.8 years and the net present value indicates that at this time the contribution would be 61,928 USD and the Benefit / cost of the project is 1.1 which is interpreted as that the benefits are greater than costs.

Figure 4 shows the cash flow diagram of the project.

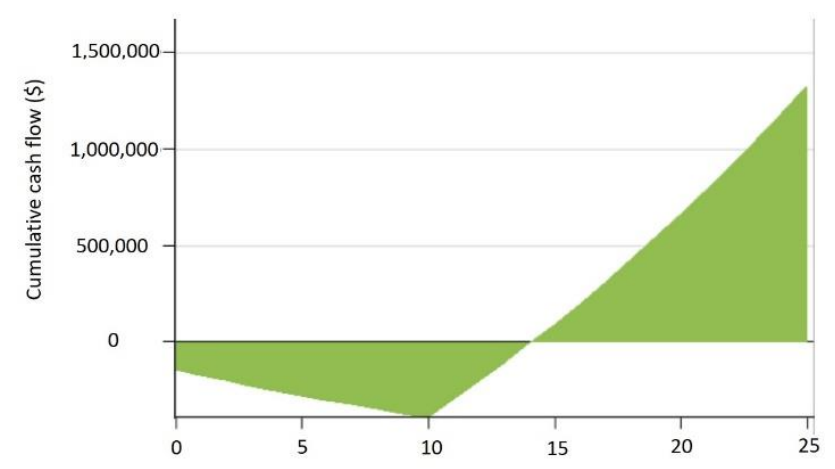

Figure 4 Cash flow diagram

Source: RETScreen, 2020

In Figure 4 the behavior of the cash flow during the project is presented, the net present value at the beginning of the project is observed and that the expenses increase in years 9 and 10 , however, between years 13 and 14 the investment and income trend continues until the end of the project.

Regarding the saved $\mathrm{CO}_{2}$ emissions, RETScreen shows that by carrying out this project, 1,318.2 $\mathrm{tCO}_{2}$ per year will be saved, which is equivalent to not using 241.1 cars or 566,414 liters of unused gasoline as shown in Figure 5.

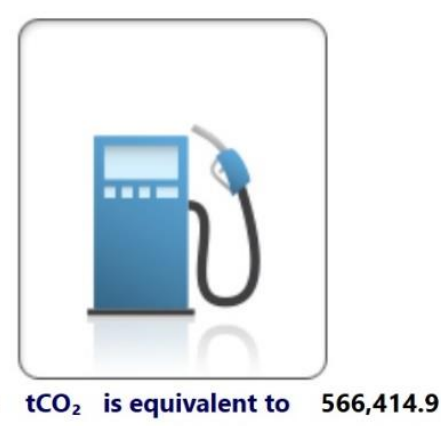

Litres of gasoline not consumed
The sensitivity analysis is based on the net present value since it is the variable most sensitive to changes, see Figure 6.

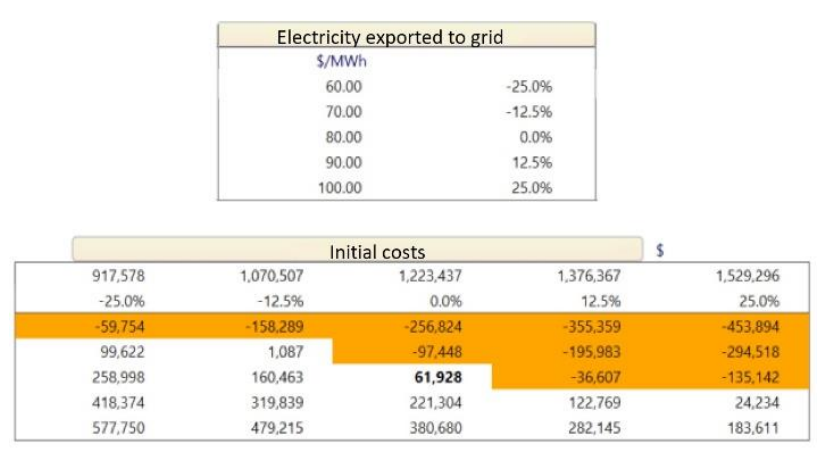

Figure 6 Reading competence

Source: RETScreen, 2020

For the sensitivity analysis carried out, it can be observed (Figure 4) that the initial costs vary according to the level of increase or decrease in the export tariff to the electricity grid, that is, as seen in Figure 4, the project It will be viable as long as the electricity export rate does not increase its cost by more than $12.5 \%$ as this will cause the initial costs to increase and make the project more expensive.

\section{Acknowledgments}

This project corresponds to the Support Program for Projects to Innovate and Improve Education (PAPIME) of the National Autonomous University of Mexico (UNAM) for the authorization of the project PE103520 entitled "Teaching for the design and evaluation of renewable energy projects for the Bachelor of Engineering in Renewable Energies".

\section{Conclusions}

The use of RETScreen software presents advantages for the evaluation of renewable energy projects, with the initial conditions of the project, a wind turbine or wind turbine brand VESTAS V44 - 40m of $600 \mathrm{~kW}$ capacity of 40 $\mathrm{m}$ of height in the state of Querétaro in the center of the country of Mexico. The initial costs of this wind turbine are $\$ 1,283 / \mathrm{kW}$ or 770,000 USD, with a tariff of $\$ 80 / \mathrm{kW}$. The electricity exported to the power grid is $1,703 \mathrm{MWh}$ and the electricity export revenue is 136,235.52 USD. 
With this wind turbine, $1,318.2 \mathrm{tCO}_{2}$ per year or 566,414 liters of unused gasoline can be saved.

Financial viability presents information that is used in projects such as the internal rate of return (IRR), which is $10.5 \%$; the return on capital is 13.8 years and the net present value indicated is 61,928 USD, as for the benefit / cost ratio of the project is 1.1 .

These results show the techno-economic viability of a renewable energy project using the RETScreen software.

\section{References}

Adetokun, B. B., Muriithi, C. M., \& Ojo, J. O. (2020). Voltage stability assessment and enhancement of power grid with increasing wind energy penetration. INTERNATIONAL JOURNAL OF ELECTRICAL POWER \& ENERGY SYSTEMS, 120. https://doi.org/10.1016/j.ijepes.2020.105988

Alkhalidi, A., Tahat, S., Smadi, M., Migdady, B., \& Kaylani, H. (2020). Risk assessment using the analytic hierarchy process while planning and prior to constructing wind projects in Jordan. WIND ENGINEERING, 44(3), 282-293. https://doi.org/10.1177/0309524X19849862

Canada, N. R. (2010, marzo 10). RETScreen. https://www.nrcan.gc.ca/energy/retscreen/7465

Enevoldsen, P., \& Sovacool, B. K. (2016). Examining the social acceptance of wind energy: Practical guidelines for onshore wind project development in France. Renewable and Sustainable Energy Reviews, 53, 178-184. https://doi.org/10.1016/j.rser.2015.08.041

Li, J., Li, S., \& Wu, F. (2020). Research on carbon emission reduction benefit of wind power project based on life cycle assessment theory. RENEWABLE ENERGY, 155, 456-468. https://doi.org/10.1016/j.renene.2020.03.133

Sikarwar, S. S., Surywanshi, G. D., Patnaikuni, V. S., Kakunuri, M., \& Vooradi, R. (2020). Chemical looping combustion integrated Organic Rankine Cycled biomass-fired power plant - Energy and exergy analyses. Renewable Energy, 155, 931-949. https://doi.org/10.1016/j.renene.2020.03.114
Wang, R., Hsu, S.-C., Zheng, S., Chen, J.-H., \& Li, X. I. (2020). Renewable energy microgrids: Economic evaluation and decision making for government policies to contribute to affordable and clean energy. APPLIED ENERGY, 274. https://doi.org/10.1016/j.apenergy.2020.115287
MENDOZA-GONZÁLEZ, Felipe, HERNANDEZ-ESCOBEDO, Quetzalcoatl, VARGAS, Alejandro and CÓRDOVA-ESCOBEDO, Jesús Fausto. Educational evaluation of renewable energy projects based on RETScreen software. Journal of Information Technologies and Communications. 2020 